\title{
Minerals from the Carpathian Mountains and from Transylvania donated by Joseph II (1785) to the Museum of the Collegio Nazareno, Rome, Italy
}

\author{
Annibale Mottana* \\ Dipartimento di Scienze Geologiche, Università \\ Roma Tre, Roma
}

\author{
Alberto Mussino, Vincenzo Nasti \\ (on behalf of Gruppo Mineralogico Romano) \\ Collegio Nazareno, Roma
}

\begin{abstract}
The mineralogical museum of the Collegio Nazareno of the Piarists Order in Rome was founded by Gian Vincenzo Petrini c. 1760. It hosted minerals and rocks the Popes had received as gifts and given to Piarists to support their teaching, as well as minerals collected from Roman and Neapolitan volcanoes. On March 24, 1769, the museum was visited by Emperor Joseph II, officially there as an incognito tourist but, in fact, to organize the election of a Pope who would abolish the Jesuit Order. On June 14, 1785 the Emperor, by now King of Hungary as well, presented eight crates of minerals from mining areas in Transylvania and Upper Hungary, i.e. Slovakia. This collection had been organized by "Baron of Born", who also wrote down descriptions of all the specimens (mostly ores), as referred to in Petrini (1791-92). The museum of the Collegio Nazareno has survived and the royal gift is partially preserved, curated by the Gruppo Mineralogico Romano (GMR), a private association of amateurs founded in 1982. The museum now exhibits a rare collection of minerals from 18th century central Europe, organized according to systematics that just preceeded the major scientific changes brought about in mineralogy by the crystallographic approach.
\end{abstract}

Key words: mineral collection, Joseph II, Petrini, Transylvania, Hungary, Romania, Slovakia

\section{Introduction}

On August 18, 1765 Francis I (also known as Francesco Stefano as the Grand Duke of Tuscany, the land he was endowed with in 1737 after renouncing his inherited duchy of Lorraine/Lothringen), the Emperor since 1745, died. As Emperor he was succeeded by his eldest son Joseph (1741-90), who took the

\footnotetext{
Addresses: A. Mottana: Largo S. Leonardo Murialdo 1, 00146 Roma, Italy; *corresponding author e-mail: annibale.mottana@uniroma3.it A. Mussino, V. Nasti: Largo del Nazareno 25, 00187 Roma, Italy

Received: March 13, 2012; accepted April 12, 2012
} 
name of Joseph II. His second son Leopold (1747-92) inherited Tuscany, moved to Florence and there ruled under the name of Pietro Leopoldo d'Asburgo-Lorena. The mother of both, Maria Theresia (1717-80), the last Habsburg to rule, became the Empress-widow, a prestigious but powerless position, and retained what both she and everybody else valued most: her inherited rank of Queen of Hungary and Bohemia etc., Archduchess of Austria, Styria, Tyrol etc. By then, she had shown herself to be a dedicated monarch and remained so, although she made her son Joseph co-regent with limited powers in some of her domains. This settlement had been agreed to by the European powers in the treaty of Aix-laChapelle (Aachen), which ended the Austrian succession war (1748).

Maria Theresia was a very conscientious, hard-working ruler, and also a careful mother. She considered it an important duty to prepare her offspring for the role they would have to play, and believed that a refined education was essential for this. All her children had excellent training in Catholic religion and international and local laws, spoke several languages, played music and - last but not least studied natural sciences. Mineralogy, then conceived as the study of all minerals and rocks, especially those useful for metal extraction, i.e ore, played a role in such training that was even greater than botany and zoology, because it assured revenues. Indeed, at that time physiocracy was the prevailing economic doctrine; it consisted in putting emphasis on productive work as the source of both national and personal wealth. Thus, most if not all Habsburg-Lothringen children studied the natural sciences under highly reputed scientists as teachers, but always kept an open eye on such practical applications as agriculture, husbandry and mining.

The teacher of mineralogy was Ignaz von Born (1742-91), a Transylvanian nobleman (Edler) born in Karlsburg/Gyulafehérvár (now Alba Iulia, Romania). In 1776 he was also appointed to organize the Imperial Museum of Vienna (the "Naturalienkammer", i.e. the forerunner of the present "Naturhistorisches Museum"), where the huge mineral collection bought by Emperor Francis I from the Florentine collector Giovanni de Baillou (1679-1758) had to be located (Wilson 1994). Born was a miner and a mine-oriented mineralogist. Thus, he not only taught the little archdukes the essential theory of mineralogy and some aspects of metallurgy and the economic value of minerals and ores, but also introduced them to mineral collecting, considered by him to be a playful but effective way of implementing knowledge and a source of practical education. A few of these childish collections still exist, usually as parts of larger collections, which some archdukes continued assembling while adults.

The mineral collection of Maria Anna (1738-89), the crippled first daughter of Francis I and Maria Theresia, which by 1780 had reached 10,000 specimens, was seized by her brother Joseph and sold to the Royal Hungarian University, which had been relocated to Buda a few years earlier (1777). What remains of it is now kept in the Eötvös Natural History Museum of the University in Budapest, 
together with many specimens from other valuable old collections accumulated during more than 200 years of history (Papp and Weiszburg 1991).

The mineral collection of Pietro Leopoldo as a teenager (242 specimens, mainly from Bohemia and the northern part of Hungary, which is now Slovakia), together with his notebooks as a student, was included in the great "Gabinetto di Fisica e Storia Naturale" he founded in Florence and constantly upgraded while he was the Grand Duke of Tuscany (Cipriani et al. 2009). In 1790, when Pietro Leopoldo left Florence for Vienna to succeed his brother Joseph II and become the Emperor Leopold II [1790-92], this Gabinetto contained 25,000 specimens, including some very rare ones collected by captain James Cook during his travels to Polynesia and Australia. This great museum, originally all within the Palazzo Torrigiani in the via Romana, is now split into various sections and partly transferred to buildings other than the original one. Nevertheless it still includes not only most minerals assembled in Florence during the so-called "Lorenese" period [1737-1860], i.e. by the Grand Dukes of the Habsburg-Lothringen dynasty, but also a few marvelous stony artefacts collected by the two branches of the previous Medici rulers [1434-1494 and 1530-1737]. Moreover, the present "Museo di Mineralogia" preserves all additions that were made after a re-organization that took place in 1881, when the unique, great museum split apart into several independent sections organized with the aim of supporting university teaching (Mottana 2011). Most samples collected by Pietro Leopoldo are still there, but their exhibition has been limited to a minimum.

The mineral collection made by Joseph II, both as a child and later on as King and Emperor, is most likely to have been kept in the "Naturhistorisches Museum" in Vienna (Niedermayr 1988; Wilson 1994). His samples are not on any special display, owing to the huge number of other beautiful specimens making their way to Vienna from everywhere in the Carpathian region during both the the Austrian Empire [1806-68] and the Austro-Hungarian dual monarchy [1868-1918]. However, there exists an independent collection, organized by (or better said - on behalf of) Joseph II. It is in Rome, at the Collegio Nazareno (Fig. 1), the teaching institution of the Piarists, i.e. the "Order of Poor Clerks Regular of the Mother of God of the Pious Schools" ("Scolopi", in Italian). There, a substantial part of Joseph II's mineral collection was duly kept throughout two and a half centuries, largely maintaining its original character. There it is now, carefully curated by the "Gruppo Mineralogico Romano" (GMR), an association of mineral amateurs and collectors founded in 1982, the main goal of which is studying the minerals occurring in the Roman Volcanic Region.

\section{Joseph II's travel to Rome in 1769}

For about two centuries the Jesuit Order had been in charge of higher education in all Catholic countries, thus shaping the minds of most members of the ruling class toward a pharisaic practice of church obligations that actually 


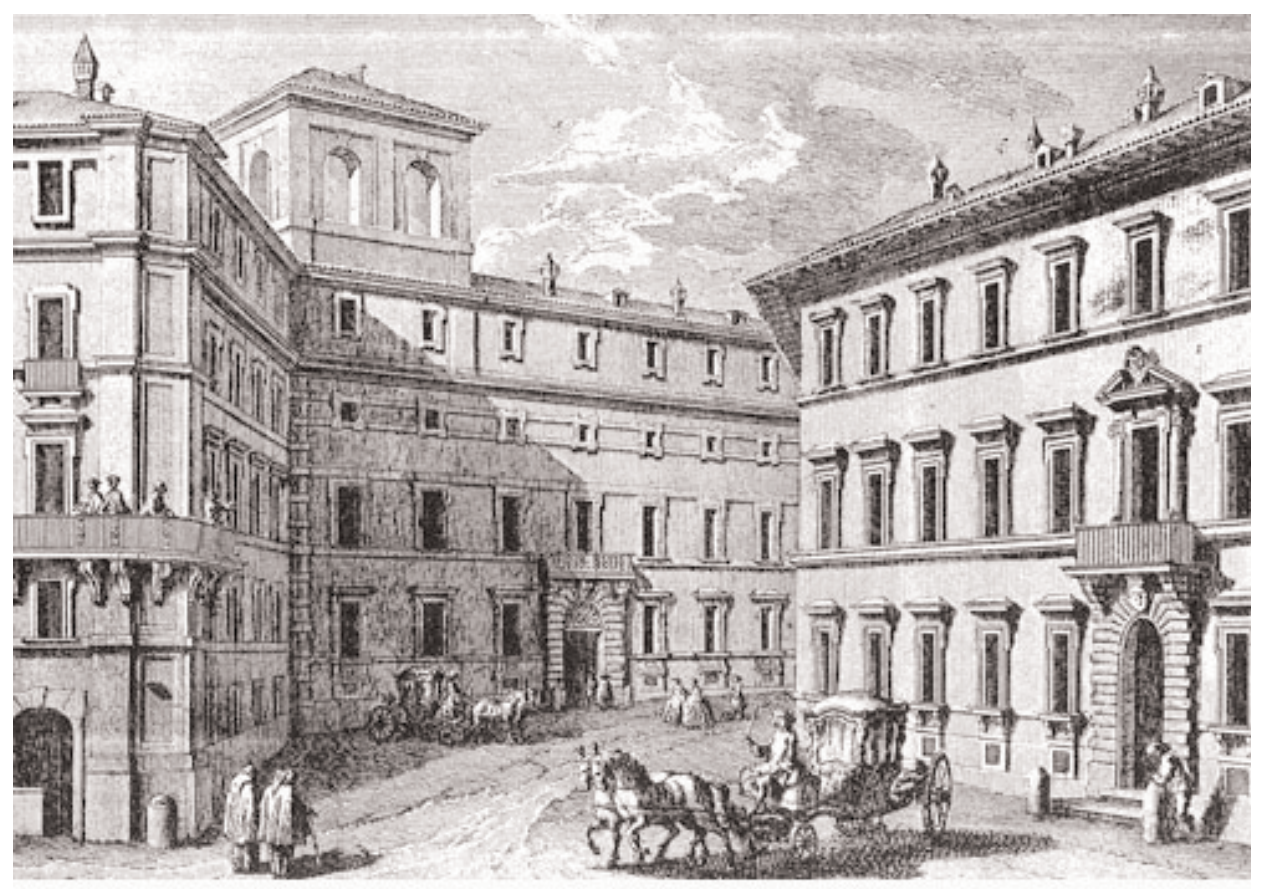

Fig. 1

Front view of Collegio Nazareno at the time of Joseph II's visit (etching by Giuseppe Vasi 1710-82)

resulted in the building up a libertine, laxist society. However, during the 1700s a new conception of education and new ideas on the relationships between lay political power and religious power developed, as it was noticed that strict education increased the development of Protestant countries, which indeed were in the full bloom of the "industrial revolution". In many Catholic countries the weight of Jesuit education began to be felt as obsolete and unbearable. Added to this was the increasing need felt by absolute monarchs to take possession of the economic wealth the company had assembled. The aim, for such monarchs, was not only to counteract the influence of the Pope on their political decisions, but also to shift the Jesuit wealth toward other goals, among which was warfare: between 1700 and 1786 European counties experienced at least four major wars, and many minor conflicts, including the American revolution.

The Bourbon Kings ruling over France had additional problems, because Enlightment was spreading among the expanding middle class ("bourgoisie"). Keeping control over this intellectual movement called for a direct, strict state control over higher education. The other Bourbon rulers - in Spain, Naples, Sicily, Parma, etc. - also became increasingly opposed to the Jesuit order and started favoring its dismissal, or at least a limitation of its power. Altogether by 1750 there was a strong Bourbon-led party in Catholic western Europe that was bitterly opposed to the Jesuits. By contrast, the Habsburg dynasty, which ruled 
over most catholic countries in central Europe, was in favor of the Jesuit order and of its form of education, as this was useful in strenghtening the minds of their people in the frequent wars against the geographically close Muslims of the Turkish Empire. The balance between the two parties would often shift around, depending on the positions taken by minor Catholic countries such as Portugal, Savoy, Venice, Bavaria, Modena, etc.

For a few decades the political situation in Europe went on as usual, albeit with occasional wars (the status quo). However, the Habsburgs increasingly lost their grip. They first started declining in the appreciation of the Pope - the final arbiter on the Jesuit controversy - when they were forced to give up domains in central Europe in favor of protestant countries such as the United Kingdom (Hannover) and Prussia (Silesia). They then experienced problems with the minor countries, because Maria Theresia had begun a policy of marrying her male children to the daughters of some decaying local dynasties with the aim of peacefully increasing the Habsburg-Lothringen empire with new lands. Consequently, after a series of settlements that only apparently conciliated the opposing parties, the turning point was eventually reached. What actually brought the situation to a bitter point was a member of the third, minor party: Portugal.

In Brazil, then a colony of the Kingdom of Portugal, the Jesuits held large areas, the "reducciones", which they administered as a sort of independent states where the natives enjoyed much more freedom than elsewhere and produced revenue, besides their basic food for living. This form of management was greatly disliked by the Portuguese colonial landowners nearby, whose economy was based on forced labor by the natives and by slaves imported from Africa. The King of Portugal also felt uneasy about being deprived of his revenues, as the Jesuit properties were tax-free. Thus, using as an excuse an attempt at killing him (which was attributed to Jesuits, probably falsely), in 1759 he banished the Jesuit order from Portugal and Brazil and confiscated all its property.

Almost at the same time an economic collapse occurred in France, which was attributed to fraud by a Jesuit, and in 1761 the Jesuit order was expelled from there as well. This touched off a cascade of bans in all the Bourbon-led states: Spain, Naples, Parma, Milan and other minor counties. Eventually, Maria Theresia herself had to surrender to such a rising tide, probably pressed by the need of reshaping the economy of her empire after the disastrous Seven Years' War [1757-63]. Cunningly, she did not play her hand openly, nor did the other Catholic princes. Rather, when Pope Clemens XIII died (1769), most rulers instructed their representatives in Rome to have a new Pope elected who would abolish the Jesuit order. The conclave began on February 15, 1769 and resulted in a long and closely-fought contest, thus giving time to Maria Theresia to send her two sons to Rome to press the issue (Magenschab 2006, pp. 108-114). Joseph II and Pietro Leopoldo arrived in Rome on March 15, officially as incognito tourists, but actually to apply all their influence on the election. They both acted strongly, but it was only on May 15 that the cardinals submitted to an agreement many of 
them did not like. The conclave ended with the election of Clemens XIV who, as a cardinal, was against the Jesuits, although moderately, and, as a Pope, was indeed reluctant to abolish the order (Guasti 2010). Eventually, however, he too had to give in: on July 21, 1773 he issued the dissolution bulla Dominus ac Redemptor. Maria Theresia first allowed the Austrian Jesuits to sell out all possible properties, then - realizing that this would actually benefit the protestant states, which deliberatly did not obey the bull - she started confiscating the remaining Jesuit establishments in her domains. As a result, in 1774 she could create a new system of well-financed, state-run schools and universities.

This is the story of when and why Emperor Joseph II travelled to Rome. He stayed in the holy city for only two weeks, mostly arguing with cardinals (the conclave regulations would not permit this to just anyone, but he, being the Emperor, had special rights). However, he also found time to visit the beauties of the eternal city, to have a double portrait made (of his brother and himself) by Pompeo Batoni (1708-87), the most celebrated painter of the time, and also to take some leisure visits. On March 24 he visited Collegio Nazareno, where the acting rector, Gian Vincenzo Petrini, introduced the mineral collection to him. At this point, a digression concerning this man of science is worth making.

\section{Gian Vincenzo Petrini, a founder of Italian Mineralogy}

As most religious leaders living in Rome at the times of papal rule, Gian Vincenzo Petrini was not a Roman by birth. He was born in Lucca, then a small independent republic in upper Tuscany, on December 5, 1725 (Ruali 1994). As most brilliant young men wishing to improve their social status, he moved to Rome at the age of 14 to enter the Calasanzio College, and joined the Piarist order before he was 16 (April 21, 1741). At 23 he graduated in theology, then philosophy and eventually in mathematics. He became a teacher and rector of Calasanzio College at 28. In just six years' time he stepped up to become the rector of the Collegio Nazareno, thus taking the lead in teaching not only poor people of Rome (this was, indeed, the mission given by José Calasanz to his charitable institution), but also of taking care for the upper education of the few wealthy pupils whose families did not like to see them tought by the Jesuits. Moreover, he entered the leading scientific circles of the city. He directed the Collegio Nazareno as rector for three successive terms [June 6, 1775 - May 17, 1784 (Pucci and Monodori 1989, p. 168)], then rose up the cursus honorum once more and became Assistant to the Father General of the Piarist Order [1784-90]. He was on track to become the Father General, and possibly even a cardinal.

Although somewhat constrained by his religious and teaching duties, Petrini's life was essentially the life of any 18th century "abbé" (e.g. René Just Haüy or Ambrogio Soldani), that is, he was free to practice his personal scientific interests as any well-to-do layman, provided he did some useful work according to the 
order mission. To begin with he organized the library of Calasanzio College, then the museum of the Collegio Nazareno. He wrote several minor essays and translated a book on animal behavior, which was printed twice (Haller 1755; Zimmerman, 1756) and was so successful as to be even copied without mentioning his name as the translator (Fabri 1757-1759).

When the French Revolution broke out (1789), Petrini, who had never shown interest in political matters but only in studying and teaching, first reacted by stressing the scientifical aspects of his mineralogical interests and wrote the book he is now remembered for (Petrini 1791-92, Fig. 2). He then indicated his intention of opening the mineralogical museum to all interested persons, not only to the Collegio Nazareno pupils, so as to increase involvement in scientific

\section{G A B I N E T T O \\ M I NER A L O G I C O \\ DEL COLLEgio NAZARENo

\author{
DESCRITTO \\ SECONDO I CARATTERI ESTERNI \\ E DISTRIB
}

A NORMA DE' PRINCIPJ COSTITUTIVI

TOMO SECONDO

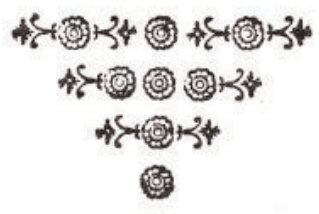

IN ROMA MDCCXCI1.

PRESSO I LAZZARINI

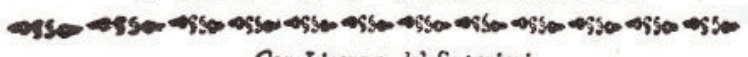

Con Licensa de' Superiori.

Fig. 2

Front page of Petrini's volume II (Rome, 1792). It contains the description of minerals, divided according to the characterizing metal and according the tripartite system of class, genus and species (with varieties). It also contains information on Joseph II's mineral gift in the form of sparse notes 
matters through a larger group of people. Indeed, this was the new educational trend the Piarist order was following, and this caused no conflict with the general interests of the church. Therefore, once, on a day when it was empty of students and with Petrini alone on duty, the College Nazareno even received on October 6, 1796, the visit of Pope Pius VI [1775-99]. The Pope found the mineralogical museum so attractive as to donate "due pezzi rispettabili di miniere del valore assai considerabile" (two large mineral specimens of very considerable value) to increase its collections (Pucci and Monodori 1989, p. 23; Crocetti et al. 1997).

However, later on, when the French revolutionary army invaded the Pope's states and Rome itself (February 15, 1797), the church's attitude changed. Many Piarists, including Petrini, had first cautiously agreed to the occupation, then enthusiastically joined the republican government ("Repubblica Romana" [February 15, 1798 - September 29, 1799]: Armando 1992b; Caffiero 2005). Presumably all they wanted was to continue their teaching, and believed they would do it better under a lay, benevolent autority claiming interest for a wider group of common people (Armando 1992a, 1997). However, Petrini became involved in the republican way of life more than others, thus undermining church authority. He accepted to become "tribuno", i.e. delegate of the "dipartimento del Tevere" (the district covering the Tiber Valley just north of Rome). He was rewarded with nomination as member of the newly-founded local Science Institute, the only member of the Natural History Section of the Mathematics and Physics Class (Caffiero 2005, p. 73), together with the other Piarist father Carlo Giuseppe Gismondi. The outcome was a personal disaster for him. As soon as the French revolutionary army withdrew from Rome (November 26, 1798), Petrini had to escape to save his life (Vannucci 1930, p. 140). Then, when the new Pope Pius VII [1800-23] made a settlement with general Bonaparte and was re-installed in Rome (1801), he was expelled from the Piarist order and eventually even forced to give up the clergy (1801). He retired to Lucca and there he lived precariously until he died on December 15, 1814. Only few months earlier (April, 1814), by intercession of the new Piarist Father General, who had been one of his pupils, he had been granted forgiveness by Pius VII, now so secure on his throne after Napoleon's fall as to even re-establish the Jesuit order (August 7, 1814 with the bulla Sollecitudo). A few years later, but well after Pius VII's death, a group of Petrini's pupils, led by cardinal Stefano Borgia, had a small monument for him made, which consists of an inscription and a bust attributed to the best Italian sculptor, Antonio Canova (1757-1822), but almost certainly made by one of his pupils. This monument was located in the hall of his Mineralogical Museum, as a lasting memory of Petrini and of his most remarkable realization. The museum has been moved away to another part of the building, but the monument is still in the hall, now used for other purposes.

Indeed, around 1760 Petrini had started what in the long run turned out to be his major scientific achievement - the one that established his reputation forever: he organized a "Gabinetto Mineralogico per uso della Gioventù che educhiamo", 
i.e. a mineralogical museum for the benefit of the youth we [the Piarists] educate (Petrini 1791, p. XXIII). At first he could only display a number of specimens donated by the Popes (i.e., presents to them coming from all over the world) and by some affluent members of Roman society such as, among others, Cardinal Stefano Borgia, Bishop Francisco Fabián y Fuero and Duke Lorenzo Ruspoli (Pucci and Monodori 1989; cfr. Petrini, 1792, pp. XXIII-XXVIII). Then, some years later (around 1770), he himself started collecting minerals, mostly together with an exceedingly gifted pupil of his who had already started collecting by himself: Scipione Breislak (Ruali 1989). Among the areas they explored together, in the bushland that at that time covered the Roman "campagna", was the Alban Hills volcanic district, where beautiful and rare specimens were then and are still now found (Mottana et al. 2008). In the physiocratic approach, rather than looking for perfect, clean and transparent crystals, they searched for hand specimens of "cava" or "miniera", i.e. rough samples representative of the geologic environment and considered to be appropriate for exploitation. It was this Petrini-Breislak sample collection, augmented by the attractive minerals received from patrons, that Joseph II and Pietro Leopoldo admired during their visit on March 24, 1769 (Pucci and Monodori 1989, p. 26).

\section{Joseph II's gift}

On June 14, 1785 a shipment arrived from Vienna at the Collegio Nazareno: eight crates containing carefully wrapped specimens, each one with a label glued to it, bearing a printed double-headed eagle seal and also a handwritten description. They were the gift of a grateful Emperor Joseph II (Pucci and Monodori 1989, p. 26).

Petrini acknowledges this gift in this way: "The munificence of Emperor Joseph II deserves a special mention, for the very rich collection of Minerals from his Estates, which at our request he graciously sent to the Collegio Nazareno by the way of the celebrated Baron of Born, who, for the greater pride and accomplishment of the magnificent present, also made a description of them" (Petrini 1791, p. XXV). As a matter of fact, Petrini had good reasons to feel proud: normally, such a type of present would have been made to the Pope (or to a ruling prince of an Italian state). Not even the Museo Kircheriano, the great collection of mirabilia that the Jesuit Athanasius Kircher (1602-80) had assembled at the Collegio Romano, could boast anything similar. It was a great recognition, both for the Piarist order and its teaching activity and for Petrini himself, as the acting rector of the Collegio Nazareno.

Petrini immediately began including the new samples in the already existing collection. The preface he wrote to his main work (Petrini 1791-1792) makes it clear which form of organization he chose. He first states that he was aware of the great progress made in mineralogy from 1780 on ("I progressi ... sono rapidi e sorprendenti": 1791, p. XXV), and also aware of the new chemical system 
developed by Lavoisier (he calls it "sistema neo-chimico", and gives a fairly accurate report of it: 1791, pp. XXIX-XLI). Yet he affirms that he determined to adhere to to the consolidated "sistema stalliano fondato sopra il flogisto" (1791, p. XXVIII), i.e. to the chemical system based on phlogiston rather than oxygen, which had been popularized by Stahl ("Stallio") during the previous century. This statement implies that he did not feel at ease with the most modern developments of mineral studies and that he did not consider it useful to apply them in a book intended to show the wealth of the Collegio Nazareno museum. This is important because he also states that he decided to classify minerals using an Italian nomenclature, albeit similar to the classification and nomenclature that had been developed in northern Europe from 1730 on. More precisely, he states that he will follow "il metodo non mai abbastanza lodato del valente Svedese Cronstedt " (1791, p. XXVII), which was the same as the one recently adopted by "l'illustre Wallerius " (1791, p. XXVI). However, "per evitare equivoci" (to avoid misunderstandings: 1791 p. XXVI), he also thought it best to add, occasionally, the Swedish, German, and French names to the Italian ones.

Notably, moreover, in spite of the provenance of the mineral gift from the Carpathian Mts., Petrini never mentions either the texbook on mineralogy (Scopoli 1772) or the book on Hungarian minerals (Scopoli 1776) written a few years earlier by Giovanni Antonio Scopoli: either he considered them to be obsolete when compared with the information contained in Born's descriptions accompanying Joseph II's gift, or he had no knowledge of them because they had been published in Prague. Indeed, the latter possibility seeems to be the most likely: as a rule Petrini never appears to have been aware of any of the ore and mining papers by mineralogists and miners who had been active in the Carpathian area during the second half of the 18th century.

Furthermore, Petrini makes it clear that his mineral descriptions, mostly based on external characteristics, would not take into consideration "le definizioni dei vocaboli geometrici atti a spiegare le forme dei cristalli minerali" (1791, p. XXV), i.e. he asserts that he will not adopt the morphological concepts introduced by Jean-Baptiste Romé de l'Isle and René Just Haüy. He justifies such a decision by stating: "La Geometria è oggimai ben coltivata in Italia" (1791 p. XXVI). This sharp assertion is nothing more than the acknowledgment that, in his time, Italian mineralogists had not accepted crystallography because it involved the study of solids using three-dimensional geometric methods, i.e. by rather advanced mathematics. Therefore, apparently, in Petrini's time most Italian mineralogists still conceived their science essentially as a sort of mining art, the results of which could be improved by chemical analysis (through which new useful elements were being discovered), but not yet by other methods. In particular, they were not ready to fully take into consideration the latest theoretical developments of basic chemistry, nor could they grasp the full impact of goniometry on the future development of the science of minerals. 
This being the scientific background of the two volumes, and in accordance with Petrini's decision to teach mineralogy in a systematic way, it is no wonder that the minerals (which he still names "fossili" according to the medieval Latin name fossilia) coming from the Carpathian mines, although being a wellconstrained set, were not all described at the same time, but were distributed throughout the different systematic classes listed in the two volumes of his book. These classes are given as: I. Salts, II. Earths, III. Bitumens and phlogistic bodies (1791, vol. I, pp. 35-378), and IV. Metals (1792, vol. II, pp. 1-222). The classes are then divided in genera, and these in species and varieties (1791, p. 26), all

following the well-established systematic partition which the Swedish natural science school had popularized. Furthermore, the four mineral classes are followed, as separate appendices, by three groups describing rocks. This indicates that Petrini already knew (1791, p. 17) of the partition of the mineral world in two main sections: minerals and rocks. The stone groups considered by him are: I. mechanically mixed compounds (rocks), II. volcanic bodies (tuffs and lavas), and III. petrified bodies (fossils) (1792, vol. II, pp. 223-353). Volume II (Petrini 1792) ends with many chemical tables.

\section{The imperial samples}

The descriptions of samples originating from the Carpathian Mts, thus presumably from the imperial gift (where not explicitly indicated as such), are all given in volume II (Petrini 1792) and are rather inconspicuous, as they are presented as notes to the main text (Ruali and Nasti 1997). In this text, most of the information derives from previous sources, whereas the notes list assays and examinations performed upon samples of the Collegio Nazareno museum, most probably by Petrini himself. When the provenance locality of the sample is indicated, the derivation from the imperial gift can be reasonably surmised, although it can rarely be proved. Only in one instance is a sample number (43) explicitly indicated (1792, n. XXVI, p. 68). Unfortunately there is no sample with such a label among those now present in the collection.

The very first descriptive information of any of the samples from the Carpathian area is given in note II on p. 16 (actually, 1792, p. 17, because the note is very long and continues on the following page). In the main text of $p .16$ Petrini was stating that native gold is usually alloyed with other metals, and was describing some assays useful for the identification of such metals. In the accompanying note he writes that native gold is occasionally found as crystals, especially in Transylvanian mines. He reminds the reader that according to Romé de l'Isle the primitive form of gold is "ottaedra rettangolare" (rectangular octahedral), whereas according to Brinnich it is cubic, in the form of "cubi laminosi" (cubes so flattened as to be similar to sheets), as also mentioned by Pallas. After these quotations, note II continues with an experimental observation by Petrini himself: "both forms [i.e. cube and octahedron] can be seen through the 
hand lens in a specimen from the Boiza mine in Transylvania, which is in our cabinet [i.e. the Collegio Nazareno mineralogical museum]". Then he continues: "Such gold crystallizes within fragile quarz, massive (§.136.10), and has a greenish, ash-like color; the gold twigs are dendritic, and some of them terminate as octahedra; and one sees in the vugs two cubes, one of which is solid and massive, and the other one sheet-like and hollow in the middle".

Furthermore, in the note that follows (1792, n. III, p. 20), he mentions that he had performed assays on the gold content of some imperial samples. The reference is to the samples of "oro piritoso" from the S. Maria di Loreto mine near Fazerbayer in Transylvania. He asserts that some of them turned out to be Aurich, others poor or very poor, just as Born had found. He then continues with a description of these gold-bearing pyrites: they are small, but often exhibit nice dodecahedral crystal forms, the faces being pentagons.

In evaluating Petrini's scientific dedication, it is significant that he did not rely a priori on Born's descriptions; rather, he made checks by his own means, i.e. by using either the hand lens or his limited chemical capacities. Indirectly his notes tell us that Collegio Nazareno had some optical instruments and a chemical laboratory, albeit small. Thus, the Piarists in Rome had organized the training of their pupils in an experimental way compatible with the most modern pedagogic methods of the time. These differed very much from the ones usually found in Catholic countries, where the dogmantic "ipse dixit" of Scholasticism was still prevailing.

Petrini's description of gold ends with the type that is mixed with "iron and copper sulfide and manganese". In the note $(1792, n$. IV, p. 23) he points out first that very few mines can compare with Nagyág for both quality and external characteristics of the gold minerals. Then Petrini proudly states that the sample in the Collegio Nazareno collection weighs over two pounds, and had been described by "Baron de Born" himself in Latin as "Minera auri antimonialis ditissimae qualitatis olim effossa, continet tercentos lathones auri in centumpondio" (mineral of antimonian gold extracted some time ago, contains 300 lots of gold in one hundredweight [300/3200 parts $9.5 \mathrm{wt} \% \mathrm{Au}$ ]: 1792, p. 23). The specimen obviously corresponds to nagyágite, for which Nagyág is the type locality. Indeed Nagyág was then, and still is, one of the most famous localities for gold tellurides, both for average content and for the beauty of specimens found. Possessing a sample from there weighing almost $1 \mathrm{~kg}$ and containing c. $95 \mathrm{~g}$ of $\mathrm{Au}$ metal represented a real pride for the museum, the more so as it was certified by one of the greatest mineralogists of the time and had been obtained through the Emperor. Unfortunately, such a sample was also very attractive for a thief, and ... has disappeared. Undeniably, the gold sample from the Immaculate Conception mine near Nagyág present now in the collection (n. 17; Fig. 3) is much smaller and less conspicuous than he one described by Petrini.

Following his teaching plan, after gold and platinum Petrini describes silver ores (1792, pp. 28-51). In the notes he specifically mentions two samples: one 


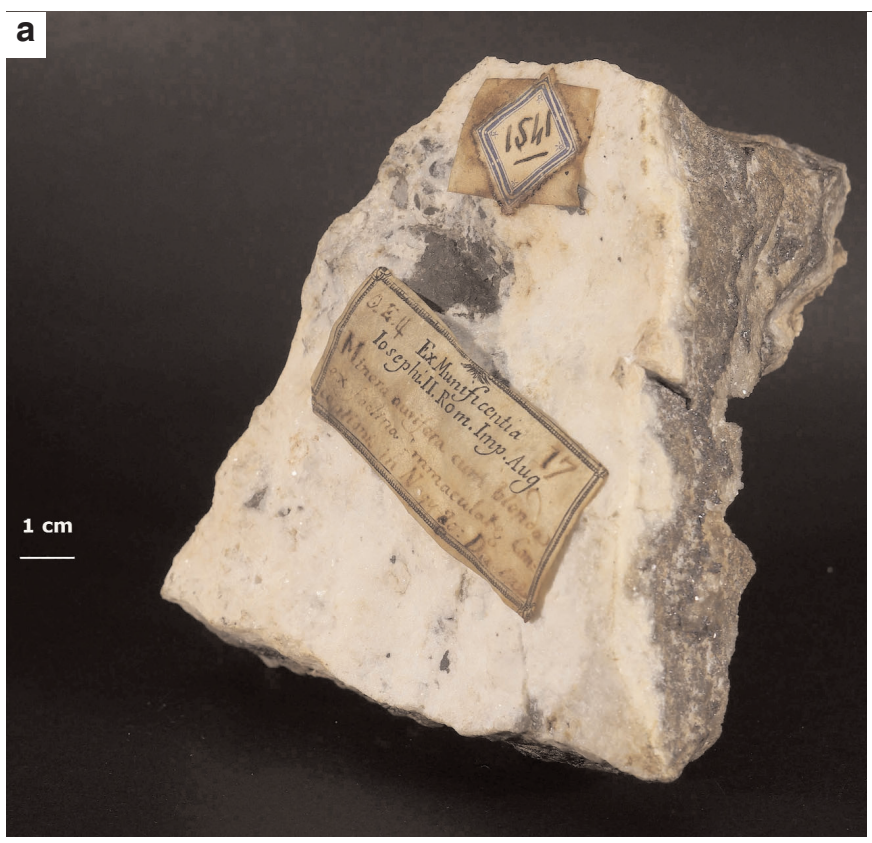

Fig. 3

Joseph II's gold sample n. 17: (a) gold telluride ore in association with sphalerite on quartz, from the Immaculate Conception mine near Nagyág (Sacarâmb) in Dacia (Transylvania, now Romania); (b) detail of the label, with the imperial crown and double-headed eagle device, the original number, the description, and the indication of the site

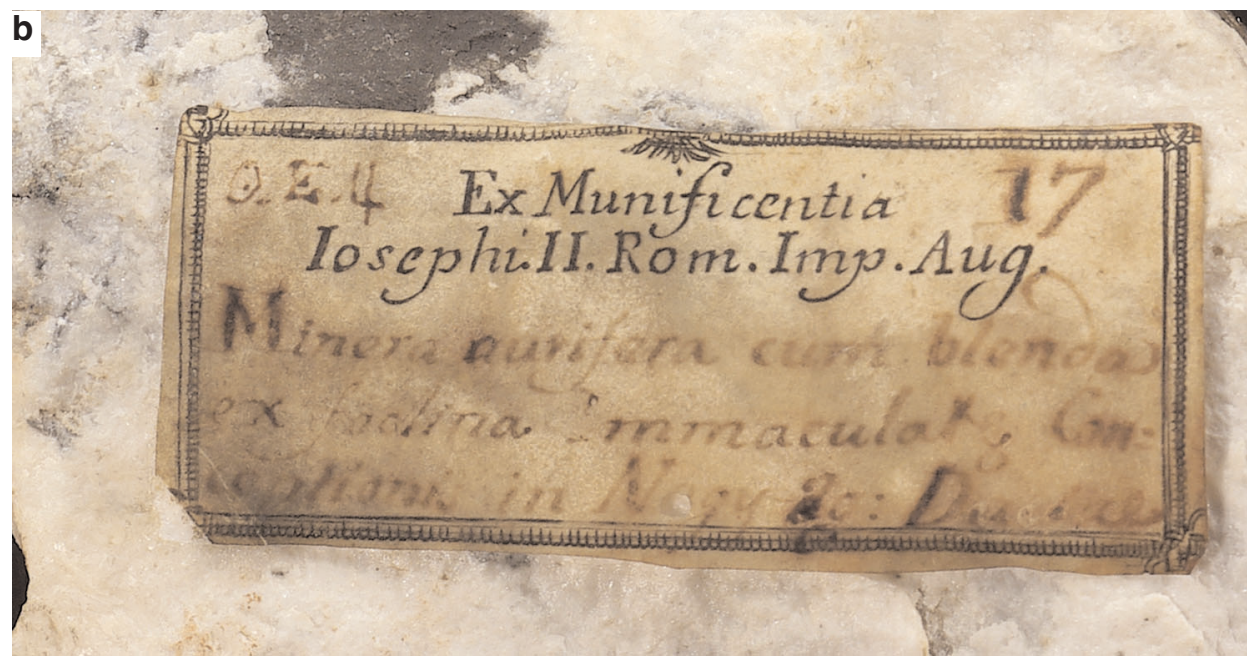

(1792, n. X, p. 32) from Schemnitz, and the other (1792, n. XIII, p. 42) from Schmoelinz, in Transylvania. Petrini describes the latter sample as being a part of "fahlertz" , i.e. a group named for ore containing various $\mathrm{Cu}$ sulphosalts, and as being set over quartz. The provenance from the imperial gift is not explicitly stated but can be surmised, as no other patron could have supplied such samples from the Carpathian region at that time. 
The description of the imperial minerals continues with nine other references (all as notes added to the various chapters of volume II, 1792, each chapter concerning a metal). Two are copper minerals (pp. 52-74; cf. 1792 n. XXVI p. 68; n. XXVIII p. 72). The former is "rame giallo" from Schmoelinz (Smolník), here correctly said to be in Upper Hungary (Slovakia). This mineral is described as being very fresh and of vivid colour with an iridescent patina; thus it would appear to be chalcopyrite, but is not. Indeed, immediately thereafter it is said to coexist with "pirite gialla" forming tetrahedral crystals. This is indeed chalcopyrite, whereas the previously mentioned "rame giallo" is probably bornite. Such a description fits very well sample n. 4 (Fig. 4). However, although similar, this is certainly not sample n. 43 here explicitly mentioned by Petrini. According to his description, the chalcopyrite present in his sample has "forma cubica", i.e. it is cubic in habit and is interspersed in "fahlertz" with bornite and siderite in a matrix of quartz. The second copper mineral is indicated as occurring in two varieties, both found in Transylvania: "gelfertz" at Sankta Barbara mine near Fuszerchs, which contains Au and is moderately Ag-rich, and an unnamed variety resting on feldspar at Sankt Anton in the Boiza valley, this one being a mine said to have been opened recently.

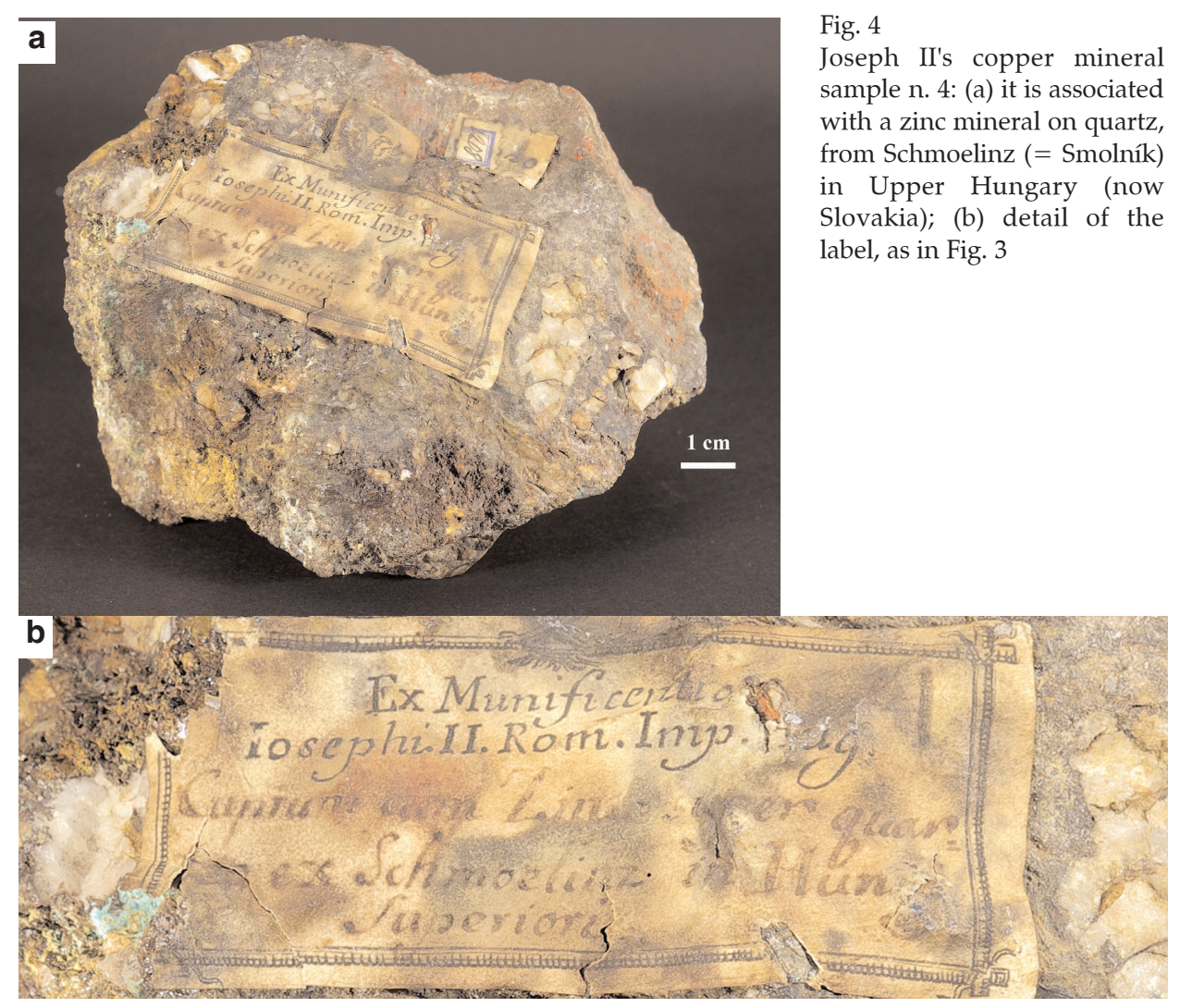

Central European Geology 55, 2012 
From p. 75 to p. 111 Petrini (1792) describes various types and occurrences of iron minerals, starting from the huge mass of ductile native iron discovered by Pallas in Siberia, which was not present in the museum and yet was too well known to be left out of the general description. He defines such mass as "problematico" (problematic; p. 76) because it contains yellow grains of "crisolito" (olivine) and has a cellular to fragmented texture. Then he quickly goes on and describes hematite, and the samples of it received from the Emperor in particular. The long note $(1792, \mathrm{n}$. XXXVI, pp. 85-86) is significant, not only because one of his descriptions matches quite well sample n. 7 (Fig. 5) still present in the Collegio Nazareno museum, but also because other samples are described and named that help to clarify the characteristics then attributed to that iron mineral. In particular Petrini emphasizes the special appearance of the Jost Monastery hematite, as this does not display the typical radiated texture of the mineral, but a complex botryoidal one. He adds that this peculiar habitus had been already pointed out

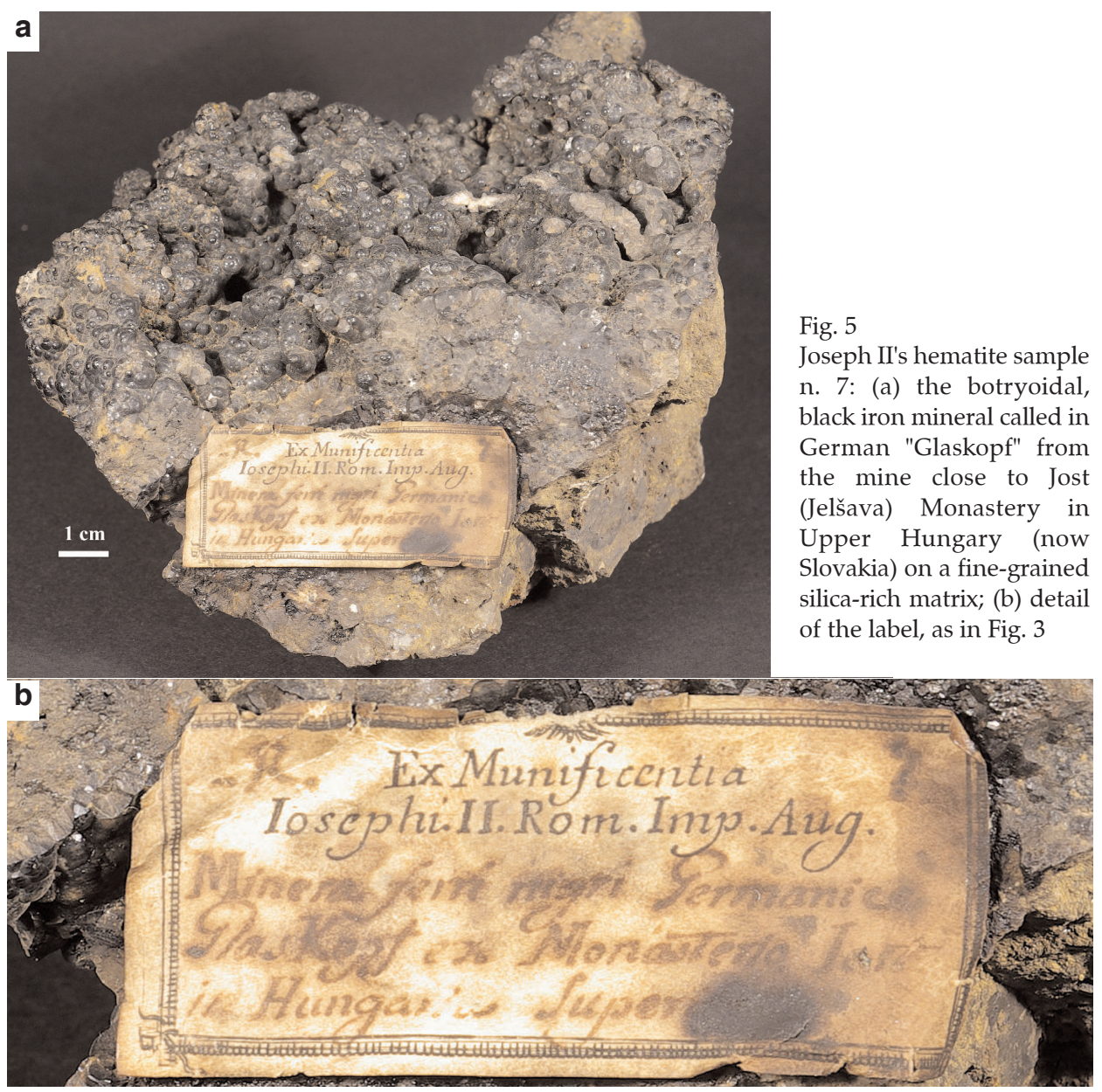


by Born. Then he enters the linguistic problem of what Germans mean by "Glaskopf", their traditional name for botryoidal hematite or limonite (goethite). He confirms that all samples named thus and present in his collection are always blackish in color, although they may differ widely in outer texture: the one from Hoffeabany is shiny and metallic with an iridescent patina; that from Jost is black but botryoidal, and looks like a cooked claystone, although another sample from the same locality looks like a bundle of thin rods; other samples, from Pyala near Vayda Hunyad, look like sheets crossing at nearly right angles that leave space in between. No wonder, therefore, if modern glossaries list under "Glaskopf" a variety of minerals ranging from psilomelane to hematite (De Fourestier 1999, p. 132). Most locality names given by Petrini mean little to us, the more so as the corresponding samples are no longer present in the collection, or, if present, they are difficult to identify precisely due to the loss of their original label. In general such names only confirm the provenance of Joseph II's samples from all over the Carpathian region.

Petrini then shifts to lead (1792, pp. 123-141). To be exact he mentions minerals from the Carpathian region when describing what he calls the sixth species of lead. The entire description is open to several questions, inasmuch as later research showed that many, if not all Transylvanian lead-bearing minerals are either mixtures of several phases or compounds of metals not yet identified in Petrini's times (Papp 2004; Szakáll 2002). Petrini himself points out the unusual outer texture of the samples named "galena antimoniale" (1792, n. LVII, p. 139), i.e. antimonian galena resting on dolomite from the Sankt Bernhard mine at Nagyág: the faces are full of streaks. Indeed, the mineral could be nagyagite rather than galena.

The Collegio Nazareno museum had few mercury samples (1792, pp. 142-150), and most of them were of minor interest. Nevertheless, Petrini mentions two localities from the Carpathian region: the Dumbrava mine near Zalathna, and Rosnau in Transylvania. Neither gets a better description then a few words about their having a hard, black, schistous matrix.

By contrast the museum was well provided with zinc minerals (1792, pp. 151-166). In particular (1792, n. LXII, pp. 151-152) Petrini points out those from Kismuntel, Kapnik, Falsebanya, Zalatna, and from the St. Francis and St. Antony mines in the vicinity of Boiza. All localities are mentioned without indicating the relative appearance of the samples. However, luckily a nice specimen is preserved (n. 10), which still bears the original label glued to it: "Pseudo galena cum pyrite in silice, quartzo et spato calcareo Kapnick in Dacia" (Sphalerite with pyrite, silex, quartz and calcite Kapnik in Dacia, i.e. obviously, Transylvania). "Pseudo-galena" is a well-known ancient name indicating dark iron-bearing sphalerite; silex is probably indicating quarz in a massive form in contrast with quarz crystals, and calcite is pointed out to be in sparry crystals ("Spath").

Antimony as a metal is dealt with in a special way (1792, pp. 167-172), not only to show that native antimony exists, as indeed it had only been discovered in 
1748 in a Swedish mine (1792, p. 168), but also to emphasize its difference from the material named in his time "antimonio", which was in fact antimony sulphide. When describing this "antimonio", i.e. stibnite, Petrini mentions two samples (1792, n. LXIX, pp. 170-171): one from Cremnitz and the other one from Toplitz, pointing out that their acicular crystals look the same in shape, but in the former locality they are large ("4 linee, 4 pollici", i.e. $10.5 \times 0.8 \mathrm{~cm}$ ) and are covered by transparent quartz, and in the second one they are needles covered by white, semi-transparent "selenite", i.e. gypsum.

Arsenic is dealt with in the same special way (1792, pp. 173-180), and native arsenic is said to be present in the collection (1792 n. LXXI, p. 175). The sample exhibits a lead-like color when broken afresh, but rapidly decays into a blackish or dark-ashen color in the open air. A green clay sample from the St. John Nepomuk mine, near Zalatna, contains, in addition to this kind of arsenic, "calce d'arsenico", i.e. arsenic oxide (arsenolite). Then Petrini enters into details which reveal him to be a careful, although poorly-equipped analyst. Using another sample, where black arsenic forms rosettes of tiny leaves resting on bluish quarz and is mixed with rosy "calce di manganese", i.e. rhodochrosite, he points out the great similarity of the material under study with what Germans call "schebern cobalt", from which a powder can be made that dissolves into water producing a solution poisonous to flies and other insects. Obviously, Petrini's chemical experiments are far too crude to warrant full understanding, but they call attention to what could be the real chemical composition of the material he studied, inasmuch as many Transylvanian minerals are known to contain odd metals and metalloids, so as to result in unexpected solid solutions and even new mineral species (e.g. museumite: Bindi and Cipriani 2004).

The description of arsenic minerals at Nagyág continues with realgar, which occurs in a manganosite sample (1792, n. LXXIV, p. 178) as both crystals and powder, alone or with auripigment, as well as together with "arsenico testaceo", i.e. native arsenic with a concentric-layered texture. This realgar exhibits forms that are rather oddly described: such a strange morphological description simply reflects the poor level of knowledge of crystallography one had in Italy at that time.

\section{Conclusions}

Joseph II's mineral gift is still present in the Museo Mineralogico of the Collegio Nazareno, although no longer in its integrity. Beside a few valuable samples that were probably stolen because of their gold content over the 250-old years intervening between their entry into the collection and today, many others have lost their original labels; thus they are hard to identify. This problem was already encountered by A. Zanotelli, the Piarist curator who drew up the 1898 manuscript catalogue of the entire museum, and he circumvented it by assuming that all samples from the Carpathian region (at that time still belonging entirely 
to the Kingdom of Hungary) had in common the same origin, i.e. they all belonged to the imperial gift of 1785 . In this way the number of samples documented as part of that gift were 60, out of a total number of 100 samples listed as originating from the entire Austro-Hungarian monarchy. A number of the missing samples was known to have been destroyed while performing practical assays. Indeed, there are records by Petrini, Gismondi, Breislak, and a few others, which show that they had used certain Carpathian specimens to carry out observations and chemical analyses. Ever since 1982, when GMR took over the keeping of the collection, such losses ceased; a new catalogue has been prepared (1997) and an attempt is under way to reconstruct as much as possible the original collection in a display where the historical significance of the imperial samples may recover all their intrinsic value.

Petrini's descriptions concern some 23 specimens, and among them only seven are unequivocally present in the collection because they still have their original labels glued to them. Other specimens, although no longer bearing their label or with the label worn out, were described by him so accurately as to still be recognizable. Nevertheless, the great majority of samples listed as coming from the Carpathian region require better examination and further study. The fact that all samples are of little but historical interest to present-day mineral collectors contributes to further uncertainty, as they are representative of mined ores from the various localities, according to the physiocratic approach to science prevailing in the 18th century. Today, the aesthetic approach, which favors beautiful exhibition specimens, prevails and leads historical samples such as the imperial ores prone to be overlooked.

However, Joseph II's samples have an added intrinsic value that escapes understanding by modern mineral collectors, and makes them valuable to scientists: they are representative of the uppermost levels of mines no longer accessible or completely worked out; thus they may contain species that can no longer be detected nor collected directly on the spot. The case of museumite, a complex mineral species from Sacarîmb [Nagyág], which could be recognized only recently because it had been confined for ages in a museum drawer under the name "nagyágite" given to it in the 1890s (Bindi and Cipriani 2004, p. 835), is compelling evidence for any scientist who would like to study again Joseph II's collection using modern methods. In particular, such samples as the "pseudogalena" and those in gold-bearing mineral assemblages, which may hide rare metals such as tellurium among their major components, are likely to offer interesting data and scientific satisfaction to their modern examiners. The characterizing geochemical feature that make Transylvania and the Carpathian Mts. surrounding the Hungarian plain to be among the most interesting mineral districts of Europe, and possibly of the whole world (60 valid mineral species: Papp 2004, p. 138), is the combination of amphoterous elements of the $5 \mathrm{~A}$ and $6 \mathrm{~A}$ groups with metal elements of the $1 \mathrm{~B}$ group. Furthermore, the upper mine horizons worked out in Joseph II's times were subject to hydratation-oxidation 
reactions that the now accessible lower mine horizons were not. Geochemistry and surface reactions would both play a role in making such testimonial samples suitable for bringing novelties to the extremely variegated world of minerals.

\section{Acknowledgements}

An early version of this study was presented orally at 12th I.M.A. General Meeting in Budapest on August 23, 2010. Thanks are due to Ekkehart Tillmanns, Tamás Weiszburg, Gábor Papp and Péter Rózsa for requesting its publication and for their patience while waiting for the manuscript to be prepared. The critical review by Gábor Papp and his friendly suggestions and communications helped to improve the text and finalizing it.

\section{References}

Armando, D. 1992a: Gli Scolopi e la repubblica giacobina romana: continuità e rotture. - Dimensioni e problemi della ricerca storica 1992, I, pp. 223-258.

Armando, D. 1992b: Gli Scolopi nelle istituzioni della Repubblica Romana del 1798-1799. - Studi Storici, 40, pp. 37-55.

Armando, D. 1997: Presenza degli Scolopi nella repubblica romana del 1798-99; pp. 561-581 - In: Fiorani,, L. (Ed.): "La rivoluzione nello Stato della Chiesa, 1789-1799. Cultura, istituzioni, praticae mentalità religiosa" Pisa: Istituto Editoriale Poligrafico Internazionale.

Bindi, L., C. Cipriani 2004: Museumite, Pb5AuSbTe2S12, a new mineral from the gold-telluride deposit of Sacarîmb, Metaliferi Mountains, western Romania. - European Journal of Mineralogy, 16, pp 835-838.

Breislak, S. 1786: Saggio di osservazioni mineralogiche sulla Tolfa, Oriolo e Latera. - Roma: Zempel. Caffiero, M. 2005: La repubblica nella città del papa: Roma 1798. - Roma: Donzelli.

Cipriani, C., L. Fantoni, Poggi, A. Scarpelini 2009: Le collezioni mineralogiche del Museo di Storia Naturale dell'Università di Firenze dalle origini ad oggi. - Atti e Memorie dell'Accademia Toscana di Scienze e Lettere "La Colombaria", 70. Firenze: Olschki.

Clark, A.M. 1993: Hey's mineral index. Mineral species, varieties and synonyms (3rd ed.). - (Natural History Museum Publications). London: Chapman and Hall.

Crocetti, G., P. Mattias, P.M. Ruali 1997: Il museo naturalistico del Collegio Nazareno. Il Cercapietre. - (Numero speciale - VII settimana della cultura scientifica e tecnologica: "Museo Naturalistico Mineralogico del Collegio Nazareno"), pp. 7-21.

De Fourestier, J. 1999: Glossary of mineral synonyms. - (The Canadian Mineralogist Special Publication 2). Ottawa: Mineralogical Association of Canada.

Fabbri, G.B. 1757-1759: Sulla insensitivita ed irritabilita halleriana opuscoli di varj autori raccolti da Giacinto Bartolomeo Fabri fisico chirurgo. Parte prima nella quale si contengono tutte le cose favorevoli al sistema del chiarissimo signor Haller; Parte seconda nella quale si contengono tutte le cose opposte al sistema del chiarissimo signor Haller; Sulla insensitivita ed irritabilita halleriana supplimento agli opuscoli di varj autori. - Bologna: Girolamo Corciolani, ed eredi Colli.

Guasti, N. 2010: Clemente XIV e la diplomazia borbonica: la genesi del breve di soppressione della Compagnia di Gesù; pp. 29-77. - In: Rosa, M., M. Colonna (Eds): b"L'età di papa Clemente XIV. Religione, politica, cultura Roma: Bulzoni.

Haller. A. 1755: Sullinsensibilita e irritabilita di alcune parti degli animali. - Dissertazioni de' signori Haller Zimmerman e Castell trasportate in lingua italiana dal p. Gian Vincenzo Petrini [...] colle lettere del p. Urbano Tosetti sullo stesso argomento. Roma: Zempel. 
Klaproth, M.H. 1802: Chemische Untersuchung der siebenbürgischen Golderze, D. Blättererz. Beiträge zur chemischen Kenntniss der Mineralkörper, Dritter Band, pp. 26-34. Berlin, Rottmann.

Lupulescu, M. 1997: Nagyagite; new data and considerations. - Revue Roumaine de Géologie, 41, pp. 29-36.

Magenschab, H. 2006: Josef II. Österreichs Weg in die Moderne. - Wien: Amalthea.

Mottana, A. 2011: I 50 anni d'attività di Curzio Cipriani per la valorizzazione del Museo di Mineralogia di Firenze ("Musei Scientifici Universitari. Una grande risorsa culturale da valorizzare". - Accademia Nazionale dei Lincei, Roma, 6 maggio 2009, a cura di E. Capanna, G. Malerba and V. Vomero). Museologia Scientifica Memorie, 7, 11-19.

Mottana, A., F. Bellatreccia, G. Della Ventura. 2008: Mineralogia di Roma e della sua campagna; pp. 247-271. - In: Funiciello, R., A. Praturlon, G. Giordano (Eds): "La geologia di Roma dal centro storico alla periferia" Parte prima. Memorie descrittive della Carta Geologica d'Italia, 80. Firenze: S.E.L.C.A.

Niedermayr, G. 1988: "Nichts ist auf der Welt Schöneres": - Zur Geschichte des Mineraliensammeln; pp. 2-40. In: Glas, M. (Ed.):"Wer sammelt macht Geschichte" München: Mineralientage Katalog.

Papp, G., T. Weiszburg 1991: History of the mineral collection of Eötvös Loránd University; pp. 115-134. - In: Vitális, Gy., T. Kecskeméti (Eds): "Museums and collections in the history of Mineralogy, Geology and Paleontology of Hungary" (Annals of the history of Hungarian Geology special issue 3). Budapest: Hungarian Geological Survey and Hungarian Geological Society.

Papp, G. 2004. History of minerals, rocks and fossil resins discovered in the Carpathian Region. (Studia naturalia 15). Budapest: Hungarian Natural History Museum.

Petrini, G.V., 1791-1792: Gabinetto Mineralogico del Collegio Nazareno descritto secondo i caratteri esterni e distribuito a norma de' principj costitutivi (2 vols.). -

Pucci, A., A. Monodori 1989: Il Nazareno. Roma: s.i.e.

Ruali, P.M., V. Nasti 1997: La collezione mineralogica. Il Cercapietre (Numero speciale - VII settimana della cultura scientifica e tecnologica: - "Museo Naturalistico Mineralogico del Collegio Nazareno"), 23-26.

Ruali, P.M. 1989: In memoria di Scipione Breislak. - Il Cercapietre, n. 16, 2-6.

Ruali, P.M. 1994: In memoria di Gian Vincenzo Petrini. - Il Cercapietre, n. 21, 6-10.

Scopoli, J.A. 1772: Principia mineralogiae systematicae et practicae succincte exhibentia structurae telluris, systemata mineralogica, lapidum classes, species, cum praecipuis varietatibus. - Pragae: Gerle.

Scopoli,J.A. 1776: Crystallographia Hungarica pars 1. exhibens crystallos indolis terrae cum figuris rariorum. - Pragae: Gerle.

Soldani, A. 1794: Sopra una pioggetta di sassi accaduta la sera de' 16. giugno del 1794. In Lucignan d'Asso nel Sanese: dissertazione del P.D. Ambrogio Soldani. - Siena: Rossi.

Szakáll, S. (Ed.) 2002: Minerals of the Carpathians. - Munich: Weise.

Vannucci, P. 1930: Il Collegio Nazareno, MDCIII-MCXIII. - Roma: s.n.

Wilson, W.E. 1994: The history of mineral collecting 1530-1799. With notes on twelve hundred early mineral collectors. - Mineralogical Record, 25 [6], pp. 1-263.

Zimmerman, G.G. 1756: Sull'insensibilità e irritabilità di alcune parti degli animali dissertazioni de' signori Zimmerman, e Castell, trasportate in lingua italiana dal p. Gian Vincenzo Petrini [...] con due lettere del p. Urbano Tosetti sullo stesso argomento. - Napoli: Gessari. 